\title{
Repeat Percutaneous Radiofrequency Ablation of T1 Renal Cell Carcinomas is Safe in Patients with Von Hippel-Lindau Disease
}

\author{
Joel Wessendorf ${ }^{1} \cdot$ Alexander König $^{1} \cdot$ Hendrik Heers $^{2} \cdot$ Andreas H. Mahnken $^{1}$
}

Received: 18 April 2021/Accepted: 22 July 2021 / Published online: 19 August 2021

(C) The Author(s) 2021

\begin{abstract}
Purpose Patients with Von Hippel-Lindau disease often develop multifocal, metachronous renal cell carcinomas which require therapy. The purpose of this retrospective single-center study is to evaluate the outcomes of radiofrequency ablation (RFA) in the treatment of renal cell carcinomas in patients with Von Hippel-Lindau disease.

Materials and Methods 9 patients (4 male, 5 female, $47.9 \pm 10.7$ y/o) with Von Hippel-Lindau disease underwent $18 \mathrm{CT}$-guided percutaneous RFA procedures for the treatment 21 renal cell carcinomas (largest diameter: $32.9 \pm 8.6 \mathrm{~mm}$, cT1a: 16, cT1b: 5). Seven patients were previously treated either by partial or radical nephrectomy. Technical success, effectiveness, safety, progression-free survival, overall survival and tumor characteristics were analyzed.

Results All RFA procedures were technically successful without major complications. There were 5 minor complications. No residual or recurrent tumor was seen in the ablation zone during a follow-up of $34.0 \pm 18.1$ months (0-58 months). No patient required dialysis during followup. One patient died after 63 months after the first treatment due to complications from a cerebellar heman-
\end{abstract}

Andreas H. Mahnken

mahnken@med.uni-marburg.de

1 Department of Diagnostic and Interventional Radiology, Marburg University Hospital, D, Philipps University Marburg, Baldingerstrasse, 35043 Marburg, Germany

2 Department of Urology, Marburg University Hospital, D, Baldingerstrasse, 35043 Marburg, Germany gioblastoma. No endpoint was reached for overall or progression-free survival.

Conclusions The results from this limited case series suggest that RFA of RCCs in patients with VHL is a safe and effective therapy, which can preserve sufficient renal function even after renal surgery.

Keywords Von Hippel-Lindau disease · Renal cell carcinoma - Renal tumor - Renal mass ·

Radiofrequency ablation

\section{Introduction}

Patients with Von Hippel-Lindau disease (VHL) are predisposed to hereditary renal cell carcinomas (RCC) to which their mortality and morbidity are closely related [1]. These hereditary RCCs are known for multifocal syn- and metachronous development [2-4]. These characteristics set hereditary RCCs in VHL patients apart from sporadic RCCs.

Due to the special characteristics of RCCs in VHL patients, tumor control aims to prevent metastatic disease, which is unlikely to occur in tumors $<3 \mathrm{~cm}$ [5]. The main goals for VHL patients are tumor control and preservation of renal function. Both need to be achieved throughout multiple treatments.

Therefore, VHL patients need a repeatable nephronsparing technique to achieve tumor control. Currently, there is a disparity between urological guidelines, which suggest partial nephrectomy (PN) [6, 7] and studies reporting promising outcomes for thermal ablations [8-12]. 
Table 1 Patient characteristics (NSS = nephron-sparing surgery; RN = radical nephrectomy)

\begin{tabular}{|c|c|c|c|c|c|c|c|c|c|}
\hline Patient & $\begin{array}{l}\text { Age } \\
\text { (years) }\end{array}$ & Surgery & $\begin{array}{l}\text { Total } \\
\text { tumors }\end{array}$ & $\begin{array}{l}\text { Tumors treated / } \\
\text { sessions }\end{array}$ & TNM stage & $\begin{array}{l}\text { Oncologic } \\
\text { outcome }\end{array}$ & $\begin{array}{l}\text { Imaging follow- } \\
\text { up (months) }\end{array}$ & $\begin{array}{l}\text { eGFR } \\
\text { change }\end{array}$ & $\begin{array}{l}\text { Functional follow- } \\
\text { up (months) }\end{array}$ \\
\hline 1 & 36 & - & 2 & $2 / 2$ & $2 \times$ cTla & $\begin{array}{l}\text { Tumor } \\
\text { control }\end{array}$ & 20 & $-22,18 \%$ & 74 \\
\hline 2 & 45 & NSS & 12 & $3 / 3$ & $\begin{aligned} 1 \times \mathrm{cT} 1 \mathrm{a} \\
2 \times \mathrm{Tc} 1 \mathrm{~b}\end{aligned}$ & $\begin{array}{l}\text { Tumor } \\
\text { control }\end{array}$ & 54 & $-39,72 \%$ & 54 \\
\hline 3 & 45 & - & 2 & $2 / 1$ & $2 \times$ cT $1 \mathrm{a}$ & $\begin{array}{l}\text { Tumor } \\
\text { control }\end{array}$ & 36 & - & - \\
\hline 4 & 62 & NSS & 6 & $2 / 2$ & $2 \times$ cT $1 \mathrm{a}$ & $\begin{array}{l}\text { Tumor } \\
\text { control }\end{array}$ & 48 & $-36,47 \%$ & 49 \\
\hline 5 & 29 & NSS & 19 & $5 / 4$ & $\begin{array}{l}3 \times \mathrm{cT} 1 \mathrm{a}, \\
2 \times \mathrm{Tc} 1 \mathrm{~b}\end{array}$ & $\begin{array}{l}\text { Tumor } \\
\text { control }\end{array}$ & 58 & $-79,06 \%$ & 57 \\
\hline 6 & 61 & $\mathrm{RN}$ & 2 & $2 / 2$ & $2 \times$ cT $1 \mathrm{a}$ & $\begin{array}{l}\text { Tumor } \\
\text { control }\end{array}$ & 27 & $-47,20 \%$ & 27 \\
\hline 7 & 49 & NSS & 1 & $1 / 1$ & $1 \times$ cT $1 \mathrm{a}$ & $\begin{array}{l}\text { Tumor } \\
\text { control }\end{array}$ & 0 & $-0,41 \%$ & 12 \\
\hline 8 & 51 & NSS & 3 & $2 / 1$ & $2 \times$ cT $1 \mathrm{a}$ & $\begin{array}{l}\text { Tumor } \\
\text { control }\end{array}$ & 35 & $-22,39 \%$ & 22 \\
\hline 9 & 53 & NSS & 5 & $2 / 2$ & $\begin{aligned} & 1 \times \mathrm{cT} 1 \mathrm{a} \\
& 1 \times \mathrm{Tc} 1 \mathrm{~b}\end{aligned}$ & $\begin{array}{l}\text { Tumor } \\
\text { control }\end{array}$ & 28 & $-15,39 \%$ & 21 \\
\hline
\end{tabular}

The aim of this study is to evaluate the oncologic outcome and renal function after RFA in the therapy of cT1 RCCs in VHL patients.

\section{Patients and Methods}

Data of all patients diagnosed with VHL who underwent RFA for RCCs in a single tertiary referral center were anonymized and retrospectively evaluated.

Nine patients ( 4 male; 5 female) with 21 RCCs (largest diameter: $32.9 \pm 8.6 \mathrm{~mm}$, cT1a: 16 , cT1b: 5) were treated during 18 RFA procedures (Table 1). Indications for therapy were either a tumor growth $>0.5 \mathrm{~cm} /$ year or a tumor diameter $>3 \mathrm{~cm}$. Prior to therapy tumor diameters and TNM score were assessed. Before the first ablation, the tumor number was counted, and the baseline eGFR was determined using the MDRD equation. Four tumors were embolized within $24 \mathrm{~h}$ prior to RFA with 250-700 $\mu \mathrm{m}$ microparticles and microcoils if needed. The indication to embolize was a case-by-case decision depending on tumor size and location. All ablations were performed under general anesthesia with non-fluoroscopic CT-guidance using posterolateral approach as previously described [13] (peak power output: 50-200 Watt; duration of energy deposition: $36.8 \pm 17.9 \mathrm{~min}(10-83 \mathrm{~min}))$. The used applicator was a LeVeen electrode (Boston Scientific Corp. Natick, MA) sized equal to the largest tumor diameter or slightly larger. Cold pyeloperfusion with saline solution ( $n=6)$ and/or hydrodissection with a glucose solution $(n=6)$ were performed to protect the bowel or ureter near if closer than $5 \mathrm{~mm}$ to the target tumor.
The day after ablation cross-sectional imaging was performed to evaluate success of ablation, complications, the ablation zone and ablative margin. The ablation was considered complete if contrast enhancement was absent in the area of the former tumor. After one ablation, no contrast agent was used due to chronic kidney disease. Instead, protein denaturation in MRI was used to conclude complete ablation. Complications were assessed using the CIRSE classification of complications [14], the SIR classification system for complications by outcome [15] and the ClavienDindo classification [16]. Ablation zone size was measured by determining the three largest diameters that are perpendicular to each other, and ablative margin was calculated using tumor diameters and ablation zone diameters.

Further follow-up imaging included a contrast-enhanced CT or MRI scan 4 to 6 months after ablation and every 6 months thereafter.

The paired two-sample Student's t test was performed to analyze eGFR. A $p$ value $<0.05$ was considered statistically significant. Statistics were computed using IBM SPSS Statistics 27 (International Business Machines Corporation, Armonk, NY, the USA).

\section{Results}

All target tumors were successfully ablated during the initial procedure. Technical success rate and technique effectiveness rate were both $100 \%$ with a minimum ablative margin of $1.0 \mathrm{~mm}$. There was no residual or recurrent tumor in the ablated area during an imaging follow-up of $34.0 \pm 18.1$ months (0-58 months). Follow-up imaging 
Table 2 Types and treatment of procedures-related complications

\begin{tabular}{lllll}
\hline Complication & $\begin{array}{l}\text { CIRSE } \\
\text { classification }\end{array}$ & $\begin{array}{l}\text { SIR } \\
\text { classification }\end{array}$ & $\begin{array}{l}\text { Clavien-Dindo } \\
\text { classification }\end{array}$ & Therapy \\
\hline Asymptomatic pneumothorax & 1 & Minor, A & 1 & No therapy \\
Urinary bladder tamponade and hematuria & 3 & Minor, B & 1 & Irrigation catheter \\
Hematuria and urine leak in preparation for RFA & 3 & Minor, B & 1 & Irrigation catheter \\
Urinary tract infection and hematuria & 3 & Minor, B & 2 & Cefuroxim 250 mg \\
Skin burn & 3 & Minor, B & 3 & Excision and suture \\
\hline
\end{tabular}

regularly showed involution of the ablation zone. One patient died 63 months after the first treatment due to complications of a cerebellar hemangioblastoma.

Post-procedural laboratory parameters of one patient were not available, so the patient was excluded from the analysis of functional outcome. No patient required dialysis during follow-up. The mean eGFR declined over $39.5 \pm 21.9$ months (12-74 months) by $-32.9 \pm 23.9 \%$ from $65.7 \pm 20.7$ to $46.5 \pm 25.3 \mathrm{ml} / \mathrm{min}(P<0.05)$.

Five $(27.8 \%)$ minor complications and no major complication occurred (Table 2). No complication prolonged the hospitalization or affected the treatment result. The hematuria and small urine leak were caused by a Mono-Jcatheter insertion for retrograde pyeloperfusion in preparation for RFA.

In all ablations, the post-procedurally assessed ablation zone contained the entire target tumor. The minimum ablative margin size was $1.0 \mathrm{~mm}$. Further follow-up imaging regularly showed involution of ablation zone.

\section{Discussion}

The presented data illustrate that repeated thermal ablation is well suited to control renal tumors in VHL patients, while preserving sufficient renal function and avoiding dialysis. The oncologic outcome of this case series is consistent with previously published data [8-12]. Furthermore, this study displays RFA's ability to achieve tumor control in larger tumors than reported previously in VHL patients, where lesion size ranged from 1.9 to $2.6 \mathrm{~cm} \mathrm{[8-11].}$

The complication rates of $0 \%$ major complications and $28 \%$ minor complications compare favorably to previously published complication rates of up to $8 \%$ major complications and up to $66 \%$ minor complications [8, 9]. Although Wei et al. [17] concluded no significant difference in overall complication rates between RFA and nonrepeat nephron-sparing surgery (NSS), it is known that repeat and salvage NSS are more complicated than the initial NSS and associated with a higher risk for complications including loss of the treated kidney [18]. Therefore, renal ablation appears to be a safe technique and particularly well suited for repeated use.
Despite eGFR decrease sufficient preservation of renal function was achieved in every patient, especially considering chronic kidney disease in 3/9 patients prior to therapy and history of renal surgery in $7 / 9$ patients. No patient became dependent on dialysis during follow-up. Data on renal function are not comparable to previous reports on renal RFA, as they evaluated the change in eGFR between the initial RFA and the last RFA. This study provides data on the long-term eGFR change. In studies with similar tumor sizes, a better preservation of renal function was observed after RFA, when compared to NSS [17, 19].

A unique feature of this study is the information regarding the ablative margin after renal RFA, whose recommended size is currently not agreed upon. In this study, oncologic control was achieved with a mean ablative margin below the recommended ablative margin for hepatocellular carcinomas, which is a minimum of $5 \mathrm{~mm}$ [20]. With preservation of renal function as a main goal in the treatment of hereditary RCCs, a small ablative margin was intended in all procedures. Considering the oncologic outcome in this case series, an ablative margin of $\geq 5 \mathrm{~mm}$ might not be necessary in the therapy of RCCs in VHL patients.

Thermal ablation compares favorably to the current gold standard of NSS as it is better suited to preserve renal function and excellent safety, even when performed repeatedly. When compared with the outcomes of cohorts with similar tumor size and comorbidities, it has no significant disadvantage in local tumor control and survival [11, 17-19].

Like previous reports, this study is limited by the low number of patients (range in the literature 6-14 patients) [8-11]. However, this case series provides information on a relevant number of tumors and procedures.

In conclusion, physicians should consider thermal ablation in the therapy of hereditary RCCs in VHL patients.

Funding Open Access funding enabled and organized by Projekt DEAL. This study was not supported by any funding.

\section{Declarations}

Conflict of interest The authors declare that they have no interest of conflict. 
Formal Consent The study was performed under a waiver from the local ethics committee.

Informed Consent For this type of study, informed consent is not required.

Consent for Publication For this type of study, consent for publication is not required.

Open Access This article is licensed under a Creative Commons Attribution 4.0 International License, which permits use, sharing, adaptation, distribution and reproduction in any medium or format, as long as you give appropriate credit to the original author(s) and the source, provide a link to the Creative Commons licence, and indicate if changes were made. The images or other third party material in this article are included in the article's Creative Commons licence, unless indicated otherwise in a credit line to the material. If material is not included in the article's Creative Commons licence and your intended use is not permitted by statutory regulation or exceeds the permitted use, you will need to obtain permission directly from the copyright holder. To view a copy of this licence, visit http://creativecommons. org/licenses/by/4.0/.

\section{References}

1. Maher ER, Yates JR, Harries R, Benjamin C, Harris R, Moore AT, Ferguson-Smith MA. Clinical features and natural history of von Hippel-Lindau disease. Q J Med. 1990;77(283):1151-63. https://doi.org/10.1093/qjmed/77.2.1151.

2. Walther MM, Lubensky IA, Venzon D, Zbar B, Linehan WM. Prevalence of microscopic lesions in grossly normal renal parenchyma from patients with von Hippel-Lindau disease, sporadic renal cell carcinoma and no renal disease: clinical implications. J Urol. 1995;154(6):2010-5.

3. Ploussard G, Droupy S, Ferlicot S, Ples R, Rocher L, Richard S, Benoit G. Local recurrence after nephron-sparing surgery in von Hippel-Lindau disease. Urology. 2007;70(3):435-9. https://doi. org/10.1016/j.urology.2007.04.040.

4. Solomon D, Schwartz A. Renal pathology in von Hippel-Lindau disease. Hum Pathol. 1988;19(9):1072-9. https://doi.org/10.1016/ s0046-8177(88)80089-3.

5. Duffey BG, Choyke PL, Glenn G, Grubb RL, Venzon D, Linehan WM, Walther MM. The relationship between renal tumor size and metastases in patients with von Hippel-Lindau disease. J Urol. 2004;172(1):63-5. https://doi.org/10.1097/01.ju.0000132127.79974.3f.

6. Campbell S, Uzzo RG, Allaf ME, Bass EB, Cadeddu JA, Chang A, Clark PE, Davis BJ, Derweesh IH, Giambarresi L, Gervais DA, Hu SL, Lane BR, Leibovich BC, Pierorazio PM. Renal mass and localized renal cancer: AUA guideline. J Urol. 2017;198(3):520-9. https://doi.org/10.1016/j.juro.2017.04.100.

7. Ljungberg B, Albiges L, Bedke J, Bex A, Capitanio U, Giles RH, Hora M, Klatte T, Lam T, Marconi L, Powles T, Volpe A. EAU Guidelines on Renal Cell Carcinoma. EAU Guidelines Office, Arnhem, The Netherlands. https://uroweb.org/wp-content/ uploads/EAU-Guidelines-on-Renal-Cell-Carcinoma-2021.pdf. Accessed 18 Apr 2021.

8. Park BK, Kim CK. Percutaneous radio frequency ablation of renal tumors in patients with von Hippel-Lindau disease: preliminary results. J Urol. 2010;183(5):1703-7. https://doi.org/10. 1016/j.juro.2010.01.022.

9. Park SY, Park BK, Kim CK, Lee HM, Jeon SS, Seo SI, Jeong BC, Choi HY. Percutaneous radiofrequency ablation of renal cell carcinomas in patients with von Hippel Lindau disease previously undergoing a radical nephrectomy or repeated nephron-sparing surgery. Acta Radiol. 2011;52(6):680-5. https://doi.org/10.1258/ ar.2011.100435.

10. Iwamoto Y, Kanda H, Yamakado K, Soga N, Arima K, Takeda $\mathrm{K}$, Sugimura Y. Management of renal tumors in Von HippelLindau disease by percutaneous CT fluoroscopic guided radiofrequency ablation: preliminary results. Fam Cancer. 2011;10(3):529-34. https://doi.org/10.1007/s10689-011-9440-3.

11. Yang B, Autorino R, Remer EM, Laydner HK, Hillyer S, Altunrende F, White MA, Khanna R, Stein RJ, Haber GP, O'Malley CM, Kaouk JH. Probe ablation as salvage therapy for renal tumors in von Hippel-Lindau patients: the Cleveland Clinic experience with 3 years follow-up. Urol Oncol. 2013;31(5):686-92. https://doi.org/ 10.1016/j.urolonc.2011.05.008.

12. Carrion DM, Linares-Espinós E, Ríos González E, Bazán AA, Alvarez-Maestro M, Martinez-Pineiro L. Invasive management of renal cell carcinoma in von Hippel-Lindau disease. Cent Eur J Urol. 2020;73(2):167-72. https://doi.org/10.5173/ceju.2020.0004.

13. Mahnken AH, Rohde D, Brkovic D, Günther RW, Tacke JA. Percutaneous radiofrequency ablation of renal cell carcinoma: preliminary results. Acta Radiol. 2005;46(2):208-14. https://doi. org/10.1080/02841850510015938.

14. Filippiadis DK, Binkert C, Pellerin O, Hoffmann RT, Krajina A, Pereira PL. Cirse quality assurance document and standards for classification of complications: the cirse classification system. Cardiovasc Intervent Radiol. 2017;40(8):1141-6. https://doi.org/ 10.1007/s00270-017-1703-4.

15. Sacks D, McClenny TE, Cardella JF, Lewis CA. Society of Interventional Radiology clinical practice guidelines. J Vasc Interv Radiol. 2003;14(9 Pt 2):S199-202. https://doi.org/10.1097/ 01.rvi.0000094584.83406.3e.

16. Dindo D, Demartines N, Clavien PA. Classification of surgical complications: a new proposal with evaluation in a cohort of 6336 patients and results of a survey. Ann Surg. 2004;240(2):205-13. https://doi.org/10.1097/01.sla.0000133083.54934.ae.

17. Wei X, Ren X, Ding Y, Wang H, Li Y, Li X, Gao Y. Comparative outcomes of radio frequency ablation versus partial nephrectomy for T1 renal tumors: a systematic review. Transl Androl Urol. 2019;8(6):601-8. https://doi.org/10.21037/tau.2019.10.13.

18. Bratslavsky G, Liu JJ, Johnson AD, Sudarshan S, Choyke PL, Linehan WM, Pinto PA. Salvage partial nephrectomy for hereditary renal cancer: feasibility and outcomes. J Urol. 2008;179(1):67-70. https://doi.org/10.1016/j.juro.2007.08.150.

19. Sung HH, Park BK, Kim CK, Choi HY, Lee HM. Comparison of percutaneous radiofrequency ablation and open partial nephrectomy for the treatment of size- and location-matched renal masses. Int J Hyperth. 2012;28(3):227-34. https://doi.org/10.3109/ 02656736.2012.666319 (PMID: 22515344).

20. Ahmed M, Solbiati L, Brace CL, Breen DJ, Callstrom MR, Charboneau JW, Chen MH, Choi BI, de Baère T, Dodd GD 3rd, Dupuy DE, Gervais DA, Gianfelice D, Gillams AR, Lee FT Jr, Leen E, Lencioni R, Littrup PJ, Livraghi T, Lu DS, McGahan JP, Meloni MF, Nikolic B, Pereira PL, Liang P, Rhim H, Rose SC, Salem R, Sofocleous CT, Solomon SB, Soulen MC, Tanaka M, Vogl TJ, Wood BJ, Goldberg SN, International Working Group on Image-guided Tumor Ablation; Interventional Oncology Sans Frontières Expert Panel; Technology Assessment Committee of the Society of Interventional Radiology; Standard of Practice Committee of the Cardiovascular and Interventional Radiological Society of Europe. Image-guided tumor ablation: standardization of terminology and reporting criteria-a 10-year update. Radiology. 2014;273(1):241-60.

Publisher's Note Springer Nature remains neutral with regard to jurisdictional claims in published maps and institutional affiliations. 